In a pamphlet entitled "The Threat of the Sahara", reprinted from the Journal of the Royal African Society, Prof. E. P. Stebbing reviews the available evidence of progressive desiccation and discusses the causes. These can be summarized as war, primitive methods of agriculture, excessive grazing and pasturage and fire. Intertribal warfare has laid waste great tracts and so promoted soil erosion. The method of shifting cultivation, entailing the cutting down of successive areas of forest and their abandonment when annual burning produces too poor a supply of fertilizing wood ash, has allowed the spread of scrub land. This degraded forest is given over to pasturage which tends to destroy the vegetation, the last stage in its use being the pasturing of goats. Prof. Stebbing sees little evidence that the desiccation can be attributed to climatic oscillations, and is extremely doubtful that the succession of a wet period will reverse the present trend.

\section{The Zoological Society of Scotland}

The increase in the number of visitors to the Zoological Park near Edinburgh to just short of half a million, and a surplus on the year's working of $£ 1,708$, indicate the material success of this Society (Ann. Report Zoo. Soc. Scot., 1936-37). In other ways it has made notable progress. The new openair enclosure for tigers, which occupies the site of an old sandstone quarry, is a most striking example of the use of natural rock, and a new restaurant, made necessary by the increase of visitors, has been completed and opened. During the year five king penguin chicks were hatched, of which three were successfully reared, and amongst mammals there were born and reared lion cubs, four beavers, three llamas, a nilghai and Barbary sheep. The chimpanzee born in January 1936 has developed well, and for many years the breeding of tropical freshwater fishes has been a feature of the Carnegie Aquarium. A successful innovation was the holding of a series of meetings of members at which lectures upon, and illustrated accounts of, their investigations of animal habits and behaviour were given by experts.

\section{Survey of India}

IN 1905 the hope was expressed by the Survey of India that in twenty-five years maps of the whole Indian Empire on a scale of one inch to a mile would be available. The Annual Report for 1936 (Calcutta. 2s. $6 d$.) points out that this hope is far from realization, and that a little more than half the area is now mapped on that scale. When it was realized in 1913 that the scheme could not be completed for many years, it was decided to reduce the scale of survey for the less populous areas. As a result, twothirds of the country is now covered by modern maps ranging in scale from one inch to a quarter inch. In the year under review more than fiftythree thousand square miles was surveyed, in addition to a certain amount of revision. The report contains full index sheets to all the scales, including the sheets of the Carte Internationale on a scale of one million which cover India and adjoining lands.

\section{Motor-boat Speed Record}

ON September 1, Sir Malcolm Campbell, driving his new motor-boat Bluebird on Lake Maggiore, made two runs over a measured mile at an average speed of $203.3 \mathrm{~km}$. an hour. His boat is equipped with a single Rolls-Royce engine of 2000 h.p., similar to that of his motor-car Bluebird. Sir Malcolm has thus achieved the distinction of holding the speed record for both land and water.

\section{Announcements}

Mr. J. D. Griffitr Davies, an administrative assistant in the Higher Education Department at Leeds, has been appointed assistant secretary of the Royal Society as from September 1 in succession to Mr. R. Winckworth, who at his own request has reverted to his previous position in charge of the Society's publications.

THE following appointments and promotions have recently been made in the Colonial Service: E. F. Allen, to be agricultural officer, Malaya ; D. B. Fanshawe, to be assistant conservator of forests, British Guiana; D. E. Faulkner, to be veterinary officer, Gold Coast ; K. D. S. MacOwan, to be veterinary officer, Kenya ; J. W. Ewart, to be assistant curator of gardens, Malaya; F. R. Mason (agricultural field officer, Malaya), to be deputy director, Department of Agriculture and Fisheries, Palestine; R. W. R. Miller (director of science and agriculture, Barbados), to be director of agriculture, Zanzibar; W. D. MacGregor (senior assistant conservator of forests), to be conservator of forests, Nigeria; H. G. Wilt. shire (pathologist, Zanzibar), to be senior pathologist, Uganda; W. Horsfield (staff surveyor), to be district surveyor, Lands and Mines Department, Tanganyika; H. M. Pendlebury (curator, Selangor Museum), to be director of museums, Federated Malay States ; J. L. Tetley (assistant analyst, Imports and Exports Department, Hong Kong), to be chemist, Institute for Medical Research, Federated Malay States.

Dr. Robley D. Evans, assistant professor of physics at the Massachusetts Institute of Technology, recently received the first Theobald Smith award in medical science, consisting of a bronze medal and one thousand dollars, for his researches, which have led to a method of detecting radium poisoning before its fatal stage and a treatment for extracting radium from bones.

A USEFUt little volume on most aspects of map. making has been published under the title of "Cartography" (Special Publication No. 205. U.S. Dept. of Commerce. Coast and Geodetic Survey 1936. 60 cents). The pamphlet opens with a short historical survey, after which is a discussion of different kinds of maps and charts and their requirements. Then follows a chapter on compilation of the material for a map and a clear, though brief, account of the chief projections. The last section treats of the technique of construction. There are many reproductions of sections of various maps, American and others. 